\title{
Problems of Power and Administrative Governance in Higher Education of Uzbekistan and the Need for Modernization of the Governance System
}

\author{
Abdurasulov Abdullajon Abdukarimovich \\ Independent researcher of the Kokand State Pedagogical Institute.
}

E-mail: kamronbek.abdurasulov@mail.ru

Phone: +998916771122

\begin{abstract}
The article examines the high responsibility of Uzbekistan to the authorities and leaders in the process of reforming society within the framework of a new development process, bringing it to a new stage of development.
\end{abstract}

Key words: management, management system, orthodox management, authoritarian management, administrative and bureaucratic management.

\section{Introduction}

Today the corporate governance method is distributed, refuses an authoritarian model and an administrative bureaucratic management model in the education system of developed countries. The effectiveness of management methods based on innovative solutions proves its position today after registration of orthodox traditions of management for the new time. In the end, "a person must create intelligence in government and society. The elimination of the problems caused by the leadership is related to the introduction of socio-development technologies. The achievement of happiness and development of innate abilities does not occur by itself, but the dependence on any teachers or managers in this matter is born"[1]. The most important thing, "everyone who lives in our country, each family should feel our reforms in their lives today. For this, managers should not pursue at all levels percentage, numbers and charges, they must work to ensure vital interests for every citizen[2].

This article discusses authoritarian and administrative issues in modern management of higher education, the issues that need to be eliminated, the need to import new principles of education.

\section{Main Part}

"To date, there are many published scientific work on the culture of management and its role in the lives of higher education institutions" [3]. In particular, "scientific research in the field of educational institutions and scientific research research in this area apply notes, since the research institution is devoted to the study of various aspects of the management culture in an educational institution" [4]. Given the place of education in the life of education, it should be noted that the study of the culture of the educational institution, the formation of the culture of the organization, the practical use of the potential of the human resource is considered relevant today.

"The staff of the Office of the Department of Management in higher education institutions is a managerial tool of all behavior of the pedagogical community. Using this management instruction, the 
head of the educational institution forms a clear model of teachers, ensures a specific type of culture in its organization, improving and uses its positive shape. Because in the educational institution there will be several types of culture in the study" [5]. "Therefore, the formation of a management culture in leaders and communities is an important factor in the management of higher educational institutions. In particular, it should be noted that the relaxation of working with the personnel by the head, circumstances, such as riding relatives, were strongly condemned, each leader in management it is necessary to give a serious and accurate assessment. The relevance of this factor is determined by the sectoral forces that require production forces that require a sharp increase in human resources. Since, higher education - is the social institution of a person, its comprehensive perfection and prosperity, the condition for the realization of the interests of a person and the creator of sensitive mechanisms, a key purpose of reforms in the country" [5]. Therefore, the creation of fair and open control will ensure the effective use of human capital.

"According to the researcher of the Tashkent State Pedagogical University Rustam Shamuratov, the word "administration" is usually the active effect on the managed object or system to achieve a specific purpose. This, in turn, presents concrete planned activities. Any activity consists of an object and control systems of subjects, which consists of relations of people between these systems and represent existing interactions. Therefore, voluntary activity necessarily requires management, in certain types of activities, a person manages himself and reaches the results of the alleged, to be interacted or influenced on other persons, which is necessary, in essence, in the direction of achieving a specific goal. This is a guide, that is, the organization and coordination of human activity towards achieving a specific goal" [6]. In general, the administration is a controller for control aimed at creating a certain structure and coordinate its activities. "Guide is a managed fragment under the control of a regular, planned and objective fraction in the managed section. Such interaction provides business capacity system. Management of management, according to the results of cybernetics, develops because of the traditional pace and scientific recommendations for the management of a complex structure began to be applied in practice. Knowledge of management is largely a key source that reflects the needs of the period. The control process, on the one hand, provides, subject to the integrity of the structure, on the other hand, allows him to further improve and development. There are two main management functions: specialized and organizational functions" [7]. Therefore, it arises that the proper guidance is to improve the structure and control, and the leadership of the wrong path leads to collapse. Therefore, based on the properties of each structure, the correct direction determines the effort to select the correct management model and the effectiveness of the implementation.

In general, management has horizontal and vertical aspects that are based on mental knowledge of horizontal aspects of management, and the vertical aspects of management are based on legal and regulatory documents. "The basis of management is social, legal, psychological and theoretical knowledge. The management itself is art, and the art means - the ability" [8]. Therefore, work is productive in the pedagogical team headed by the head with leader's abilities and fundamental knowledge, the environment is healthy and the harmonic team. In the manual, human factor management as an executive, reliable, presenter requires hard work. High culture, clear strategic goals and honesty, the desire to achieve perfection, self-esteem, the growth of personal pride and the feeling of sincerity will act as a foundation in the head of the educational institution. Self-government reaches only the best teams. As Confucius said, society needs to manage morality, good deeds and traditions, 
not the law"[9]. Consequently, the display of practical results is far from bureaucratic relations and documentation in the system of higher education, one of the important and urgent tasks in the preparation of competitive personnel is to introduce accountability management methods. To do this, in managing higher education, it is necessary to properly manage the human factor, improving the quality of education through the effective organization of its pedagogical activity, the development of knowledge and skills of students, education of potential personnel. This is a change in the principles of management in higher education and compliance with adaptation by time.

In general, the development of the leadership and the assignment of the management of our society should develop a system for consideration of certain knowledge and skills in the appointment of management. Because the management is responsible, duties and is a check, the personality of the manager should have knowledge, abilities and initiative. Therefore, as a management culture, a set of cultural and educational measures aimed at achieving a certain goal and the implementation of human potential is a manifestation of their implementation. At the same time, the humanistic duty of the leadership should not forget. It is also effort to ensure that managed to ensure happiness. The famous Thunder Abu Nasr Farabi represents the following thought: "Not everyone will cope in order to lead someone else besides himself and elevate them to the level of happiness". Kaykovus, which is famous for the work of the "Kobusnama", is also known for its management and management issues. In particular, "On the child, if you are the king, be clean, keep your eyes and hands in gave the people from women. When you do anything, do it by decree of mind and do not do anything by consulting with him, as the king ministers are his mind. Know the measure of each work and think about all the work. Everything is done, the words look like a mind, so as not to watch the truth. No one ever requests anything and be merciful to others, but not pretty cruel".

Democratic management style is based on democratic principles. "The democratic leader is a person who is purposeful, calm, listens to the opinions of others, brings up his subordinates with the mind. Such management organizations have high decentralization of powers and active participation of subordinates in decision-making. The decision is controlled by the head and employees and the leader will be good to personnel". He also protects the interests of subordinates, takes into account their needs and features.

In addition to the democratic style of management, the responsibility between leaders, deputy leaders and staff is distributed in accordance with their positions. The leader that applies to this method is counting the opinion of the team about important issues of production and takes collective decisions. The staff constantly receives information about the situation in production. The head will fight for a healthy psychological environment in the team to ensure the harmony of employees and interests.

\section{Conclusion}

With a conclusion, today in Uzbekistan, the necessary tasks for the development of the higher education system are based on the priorities of the country's socio-economic development, a radical review of personnel training, to ensure the necessary conditions for the preparation of specialists in accordance with the level of international standards. Therefore, the underlying organizational and pedagogical features of corporate governance in higher educational institutions and the introduction of it to the national education system becomes one of the most important tasks. 


\section{References:}

1. Yuldashev S.U. Scientific and socio-cultural technology of society. - Tashkent. the science. 2019. - P.10.

2. Mirziyoev Sh.M. From the national rebirth - to national superiority. Volume 4 - Tashkent: Uzbekistan, 2020. - P. 48.

3. Golovneva I.V. Psychological basis of personnel management. / Tutorial for students of higher educational institutions. 2nd Publisher, Supplement and Processing - H.: Publishing House NU, 2007. -p. 152; Mahmudov I. Psychology of Management. - Tashkent.: «Unaks-print», 2005. P.170.

4. Mehtieva E. D., Solodovnikova M. N., Chernenko L. I. Simple ways to increase the culture of the pedagogical team. // "School Director", 2008, №5. -P. 32-36; Rybakova N. N. Activity manager for the formation and development of the organizational culture of an educational institution. // "Omsk Scientific Bulletin", 2007, №6. -P. 52-55.

5. Isakov Z. M Analysis of the problems of the formation of personnel management in pedagogical institutions of educational institutions. Modern education. 2017. №5. -P. 8

6. Shamuratov R. Organization of activities of higher education system and improvement of the management process technologies., Scientific Bulletin of Namangan State University: Vol. 1 : Iss. 8 , Article 70. 2019. Available at: https:/ /uzjournals.edu.uz/namdu/vol1/iss8/70

7. Ismailova Z. K, Baybaeva M. X., Improving the effective management of managers to solve conflict situations. (Monograph) - Tashkent.: Publishing House Nodirabegim. 2019. -3. 11.

8. Umarov B. Psychology. - Tashkent.: Heir publishing house. 2012. - P - 211-212.

9. Abdullayev, Yo. 99 secrets of a good life. Main book. - Tashkent.: Education. 2015. - P. 12.

10. Bakhromovich, S. I. (2020) the impact of managerial professional development on the effectiveness of Higher Education institution management. Academicia An International Multidisciplinary Research Journal (Double Blind Refereed \& Peer Reviewed Journal) Vol. 10 Issue 12, December, 2020. 